\title{
National Girl Child Day: Guest Comment
}

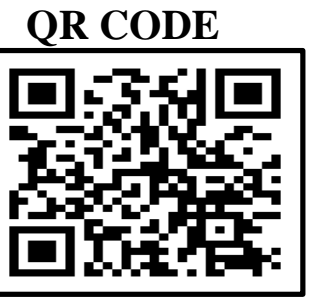

It is said that girls with dreams become women with vision. May we empower each other to carry out such vision

-Meghan Markle

Keeping in line with this thought every year since its initiation in 2008, January $24^{\text {th }}$ is celebrated as "National Girl Child Day". It works side by side other schemes for development of the girl child like "Save the Girl Child", "Beti Bachao Beti Padhao", "Sukanya Samriddhi Account", "CBSE Udaan Scheme" and many more promoting awareness of issues facing girl child in India, such as education, nutrition, child marriage, legal rights and medical care, protection, honour. India is celebrating its $15^{\text {th }}$ anniversary of National Girl Child Day or Rashtriya Balika Diwas. It commemorates every year with diverse themes aimed at empowering the girl child in diverse walks of life. Adolescent girls have the right to a safe, educated, and healthy life, not only during these critical formative years, but also as they mature into women.

If effectively supported during the adolescent years, girls have the potential to change the world -both as the empowered girls of today and as tomorrow's worker, mothers, entrepreneurs, mentors, household heads, and political leaders. An investment in realizing the power of adolescent girls upholds their rights today and promises a more equitable and prosperous future, one in which half of humanity is an equal partner in solving the problems of climate change, political conflict, economic growth, disease prevention, and global sustainability. Girls are breaking boundaries and barriers posed by stereotypes and exclusion, including those directed at children with disabilities and those living in marginalized communities. As innovators and initiators of global movements, girls are creating a world that is relevant for them and future generations. It is crystal clear that empowering a girl child is the need of the hour or present day scenario. Education of girl child has been a high priority with the government of India, according to the Right To Education act , every child of the age of $6-14$ years shall have a right to free and compulsory education in a neighbourhood school till competition of elementary education. For the success of Sarva Shiksha Abhayan or education for all, the education of girl child is a must.

No doubt, girls deserve a better deal from society at present, they say girls are no way inferior to boys but what are they getting from society? A whole range of discriminatory practices including female foeticide, female infanticide, early marriage, and dowry which have buried the future of girl child. It seems very difficult to empower the girl child. Our society is still suffering many weaknesses. Instead of giving them education, they are being subjected to sufferings and this has become part and parcel of society. Girls need more role models to aspire to the likes of women such as Dhivya Suryadevara in automobile industry, Hima Das in athletics, Arunima Sinha is a special abilities mountain climber. We also need to motivate underprivileged and unmotivated parents to avail education operative made available by the government for their children. To curb the menaces and to recognize girls and unique challenges girls face around the world, we must all stand together. 
Cite this article as:

Kaur R. National Girl Child Day: Guest Comment. Int Healthc Res J. 2022;5(10)GC1GC2. https://doi.org/10.26440/IHRJ/0510.01488

AUTHOR AFFILIATION:

BDS, Private Practitioner and Consultant Dental Surgeon, New Delhi (https://orcid.org/oooo-00o2-2216-0422)

Source of support: Nil, Conflict of interest: None declared

Contact Corresponding Author at: rknarula[at]yahoo[dot]in 